Роль ультразвукового

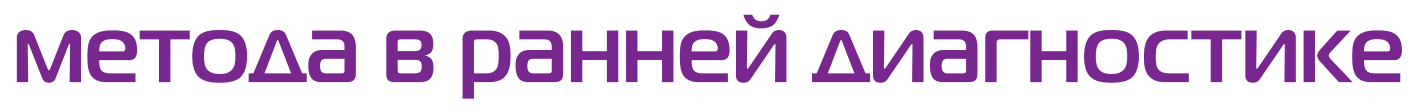

перинатальных ишемических

ИнСУАьтов. ВозможнОСтИ

Ауплексного сканирования

при определении пострадавшего

\title{
сосуАистого региона
}

\author{
Быкова Ю.К. ${ }^{1,2}$, \\ Ушакова $\Lambda$. В. $^{1}$, \\ Филиппова Е.A. ${ }^{1,2}$, \\ Ватолин K.B. ${ }^{2}$, \\ Сугак А.Б. ${ }^{1}$, \\ Амирханова А.Ю. ${ }^{1}$, \\ Быченко В.Г.1, \\ Зубков В.В. ${ }^{1,3}$
}

\begin{abstract}
1 Федеральное государственное бюджетное учреждение «Национальный меАицинский исслеАовательский центр акушерства, гинекологии и перинатомогии имени академика В.И. Кулакова" Министерства зАравоохранения Российской Федерации, 117997, г. Москва, Российская Федерация

2 Федеральное государственное бюджетное образовательное учреждение дополнительного профессионального образования «Российская медицинская академия непрерывного профессионального образования" Министерства зАравоохранения Российской Федерации, 125993, г. Москва, Российская Фелерация

${ }^{3}$ Федеральное государственное автономное образовательное учреждение высшего образования Первый Московский государственный медицинский университет имени И.М. Сеченова Министерства зАравоохранения Российской Федерации (Сеченовский Университет), 119991, г. Москва, Российская Федерация
\end{abstract}

\begin{abstract}
Ультразвуковой метод исследования играет важную роль в ранней диагностике перинатальных ишемических инсультов, позволяет выявить очаги ишемии разной локализации и размеров. Ультразвуковая допплерография повышает диагностическую ценность метода, позволяет определить состояние кровотока в пострадавшем сосудистом бассейне. Анализ ультразвуковых и клинических данных свидетельствует о том, что пост- и антенатальный ишемический инсульт имеют существенные различия. Антенатальные инсульты развиваются до рождения ребенка, локализуются в бассейне лентикулостриарных артерий, не сопровождаются очаговой неврологической симптоматикой. Постнатальные инсульты развиваются чаще всего на 2-3-и сутки жизни, проявляются очаговой неврологической симптоматикой, локализуются в корково-подкорковых отделах. Очаги ишемии при постнатальных инсультах ультразвуковым методом исследования выявляются только к концу 2-х суток заболевания. Локальные нарушения кровотока в пострадавшем сосудистом бассейне методом дуплексного сканирования выявляются с 1-го дня заболевания.
\end{abstract}

Финансирование. Исследование не имело спонсорской поддержки.

Конфликт интересов. Авторы заявляют об отсутствии конфликта интересов.

Для цитирования: Быкова Ю.К., Ушакова Л.В., Филиппова Е.А., Ватолин К.В., Сугак А.Б., Амирханова Д.Ю., Быченко В.Г., Зубков В.В. Роль ультразвукового метода в ранней диагностике перинатальных ишемических инсультов. Возможности дуплексного сканирования при определении пострадавшего сосудистого региона // Неонатология: новости, мнения, обучение. 2020. T. 8, № 1. С. 72-82. doi: 10.33029/2308-2402-2020-8-1-72-82

Статья поступила в редакцию 10.11.2019. Принята в печать 12.02.2020.
Ключевые слова: новорожденные, перинатальный артериальный ишемический инсульт, ультразвуковая диагностика 
The role of ultrasound in the early diagnosis of perinatal ischemic strokes. The possibility of duplex scanning in determination of the affected vascular region

Bykova Yu.K. ${ }^{1,2}$, Ushakova L.V. ${ }^{1}$, Filippova E.A. ${ }^{1,2}$, Vatolin K.V. ${ }^{2}$, Sugak A.B. ${ }^{1}$, Amirkhanova D.Yu. ${ }^{1}$, Bychenko V.G. ${ }^{1}$, Zubkov V.V. ${ }^{1,3}$
${ }^{1}$ Kulakov Obstetrics, Gynecology and Perinatology National

Medical Research Center of Ministry of Healthcare of the Russian

Federation, 117997, Moscow, Russian Federation

${ }^{2}$ Russian Medical Academy of Continuing Professional Education,

125993, Moscow, Russian Federation

${ }^{3}$ I.M. Sechenov First Moscow State Medical University of the

Ministry of Health of the Russian Federation (Sechenov

University), 119991, Moscow, Russian Federation
Ultrasound methods play an essential role in the early diagnostics of perinatal ischemic strokes, help to identify ischemic foci of the different localization, sizes, and blood flow in the affected vascular pool.

The analysis of ultrasound and clinical data indicates that antenatal and postnatal ischemic stroke have significant differences. Antenatal strokes develop before the delivery is usually localized in the pool of lenticularstriar arteries, and not accompanied by focal neurological symptoms.

Postnatal strokes will happen mostly on the $2^{\text {nd }}-3^{\text {rd }}$ day of life and manifested by focal neurological symptoms. They localized in the cortical-subcortical region. Foci of ischemia more visible by ultrasound only at the end of the second day of the disease. Local blood flow disorders in the affected vascular pool detected by duplex scanning from the first day of the disease.

Funding. The study had no sponsor support.

Conflict of interests. The authors declare no conflict of interests.

For citation: Bykova Yu.K., Ushakova L.V., Filippova E.A., Vatolin K.V., Sugak A.B., Amirkhanova D.Yu., Bychenko V.G., Zubkov V.V. The role of ultrasound in the early diagnosis of perinatal ischemic strokes. The possibility of duplex scanning in determination of the affected vascular region. Neonatologiya: novosti, mneniya, obuchenie [Neonatology: News, Opinions, Training]. 2020; 8 (1): 72-82. doi: 10.33029/2308-2402-2020-8-1-72-82 (in Russian)

Received 10.11.2019. Accepted 12.02.2020.

\section{Keywords:} newborns, perinatal ischemic strokes, ultrasound diagnostics
Б ольшой интерес у врачей разных специальностей, работающих в неонатологии, вызывают вопросы диагностики и лечения перинатальных инсультов. По данным разных исследователей, перинатальный артериальный ишемический инсульт (ПАИИ) регистрируется с частотой от 1:2500 до 1:5000 новорожденных; он занимает одно из ведущих мест в структуре патологии нервной системы перинатального периода [1-12]. Клинические признаки ПАИИ неспецифичны, заболевание может проявиться в виде судорожного синдрома, апноэ, синдрома угнетения, гемипареза [4-8, 12], поэтому ранняя диагностика перинатальных инсультов невозможна без современных методов нейровизуализации [1-18]. До недавнего времени считалось, что единственным методом диагностики данной патологии является магнитно-резонансная томография (МРТ) головного мозга. Но этот метод недостаточно широко распространен в практической медицине, требует транспортировки и специальной подготовки пациента, что не всегда осуществимо при его тяжелом состоянии. В связи с этим растет интерес к ультразвуковому исследованию (УзИ), несмотря на то что оценка его диагностических возможностей при ПАИИ противоречива, в значительной степени зависит от уровня используемого оборудования и опыта исследователя. На сегодняшний день доказано, что ультразвуковой метод информативен для диагностики ПАИИ и имеет достаточно высокую чувствительность (до 79-95\% для врача-эксперта и 61-83\% для неэкспертного исследователя) [1].

В ФГБУ «НМИЦАГП им. В.И. Кулакова» Минздрава России работа по изучению перинатальных инсультов проводится с 2012 г. [7, 8]. Совместными усилиями разных специалистов был разработан диагностический алгоритм, в котором ультразвуковому методу отведена важная роль (см. схему) [7].

В этой статье мы хотим более подробно описать возможности ультразвукового метода в диагностике ПАИИ, а также поделиться своими новыми наблюдениями.

Ультразвуковая картина и изменения допплерографических показателей при ПАИИ определяются патоморфологическими и патофизиологическими процессами в головном мозге. ПАИИ развивается в результате нарушения кровотока в церебральных артериях. Его причинами могут быть тромбоз, эмболия, артериальная диссекция, вазоспазм и др. [1-19]. Окклюзия артерии приводит к ишемическому повреждению дистальных отделов ткани мозга. Развитие инфаркта мозга протекает стадийно [5-7].

Первая стадия ПАИИ - развитие цитотоксического отека. В пораженной артерии кровоток может быть снижен в течение нескольких часов. Через 6 ч развивается вторая стадия, харак- 


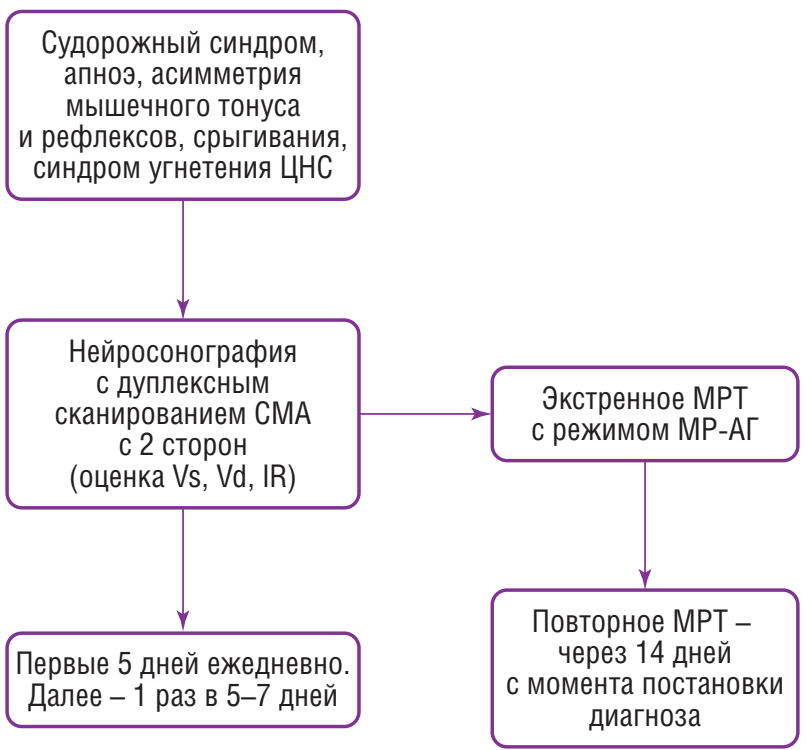

Алгоритм Аиагностики перинатального артериального ише мического инсульта на этапе стационара $[1,10,11,15]$

ЦНС - центральная нервная система; МР-АГ - магнитно-резонансная ангиография; МРТ - магнитно-резонансная томография; СМА - средняя мозговая артерия.

теризующаяся вазогенным отеком и коагуляционным некрозом, сопровождающаяся реперфузией ишемизированного участка через реканализированную артерию или через анастомозы. Клинические проявления ПАИИ в большинстве случаев появляются на стадии реперфузии. Патоморфологические изменения второй стадии наиболее выражены на 2-4-й день после развития инсульта. Отек и некроз в зоне ишемии изменяют ультразвуковую структуру тканей мозга. При Узи в В-режиме зона ишемии характеризуется повышенной эхогенностью, отечностью и нарушением дифференцировки структур $[5-7,14]$. Третья стадия - организация инфаркта - начинается с 3-го дня, длится до 6 нед. В это время происходят глиоз, распад миелина, образование микрокист, неоваскуляризация и нейрогенез. При тотальном некрозе может произойти центральное

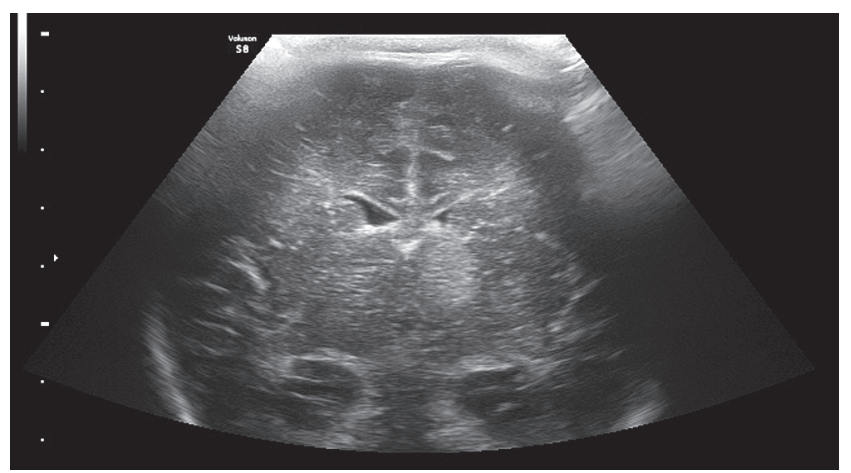

Рис. 1. Ребенок Р., 38 неА гестации, оценка по шкале Апгар 8/8 бамлов, 2-е сутки жизни. Антенатальный перинатальный артериальный ишемический инсульт. Очаг повышенной эхогенности в проекции зрительного бугра разжижение с последующим образованием кисты. Четвертая стадия начинается со 2-го месяца от начала заболевания, она характеризуется потерей ткани $[5,6]$.

Дуплексное сканирование (ультразвуковая допплерография), включающее режим цветового допплеровского картирования (ЦДК) и импульсную допплерографию (ИД), позволяет выявить изменения кровотока в сосудах, кровоснабжающих пораженный участок. Характер кровотока в пораженном сосудистом регионе меняется в зависимости от стадии инсульта $[4,6,7]$.

Нарушение кровотока и структурные изменения тканей мозга развиваются последовательно, поэтому разные типы ПАИИ имеют различную эхо- и допплерографическую картину.

В зависимости от сроков возникновения ПАИИ подразделяется на антенатальный инсульт, развивающийся с 20-й недели беременности до момента рождения ребенка, и постнатальный (неонатальный), регистрируемый у детей с момента рождения по 28-й день жизни [7, 9, 10, 19].

Антенатальный (фетальный) артериальный ишемический инсульт у доношенных новорожденных при УзИ определяется как зона повышенной эхогенности. Ишемические очаги могут располагаться в проекции подкорковых ядер (головка хвостатого ядра, бледный шар) или в зрительных буграх, т.е. в бассейне лентикулостриарных артерий (глубокие ветви средней мозговой артерии CMA) (рис. 1, 2). При антенатальном инсульте ишемический очаг, как правило, выявляется при первом, скрининговом УзИ, т.е. случайно, так как в клинической картине у этих детей нет выраженной неврологической симптоматики $[7,8]$.

При последующем динамическом наблюдении отмечается постепенное уменьшение размеров ишемических очагов.

При дуплексном сканировании у большинства детей с антенатальным ПАИИ $(n=5)$ явных гемодинамических изменений на стороне ишемии нами не выявлено, скорости кровотока в систолу (Vs) и в диастолу (Vd), а также индекс периферического сопротивления (индекс резистентности - IR) в (МА с двух сторон были симметричными. Только у 1 ребенка в CMA на стороне ишемического очага периферическое сопротивление было повышено (IR=0,79). При повторном УзИ в 1 мес периферическое сопротивление и скорости кровотока (Vs и Vd) в CMA были близкими по значению, соответствовали возрастной норме.

Таким образом, для антенатальных (фетальных) ишемических инсультов характерны следующие признаки:

- выявляются случайно, чаще всего при скрининговом УзИ мозга, не сопровождаются очаговой неврологической симптоматикой;

- локализуются в проекции базальных ганглиев и в зрительных буграх, т.е. в бассейне лентикулостриарных артерий;

- изменения кровотока в СМА, как правило, отсутствуют, в отдельных случаях могут быть неспецифичными и кратковременными.

При неонатальном (постнатальном) ишемическом инсульте у доношенных новорожденных (гестационный 


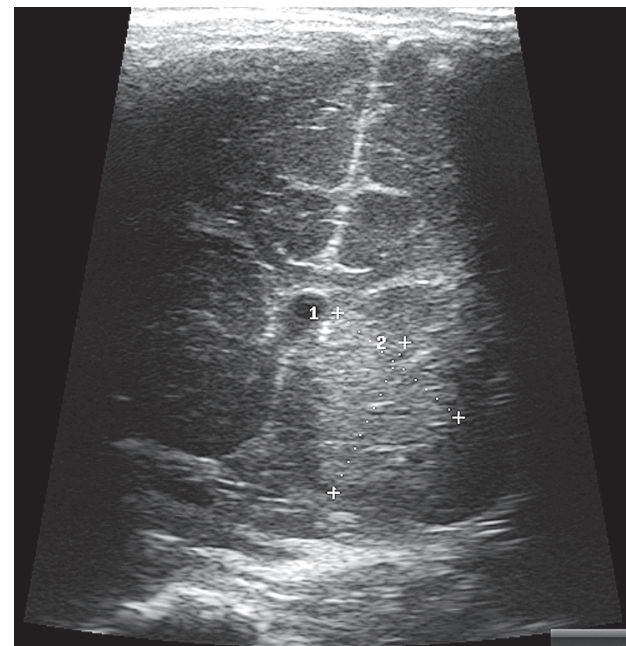

A

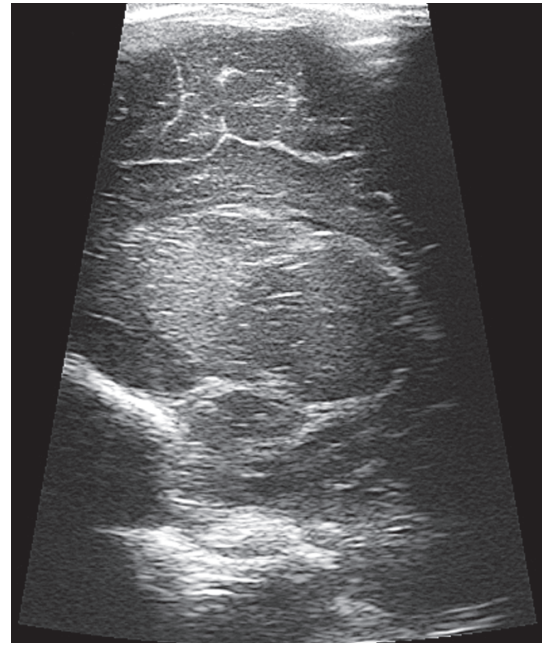

Б

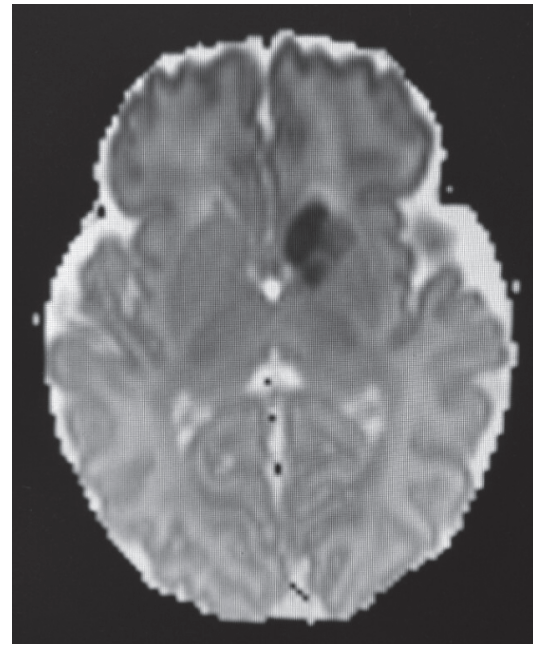

B

Рис. 2. Ребенок М., 38 неА гестации, оценка по шкале Апгар 8/9 бамлов, 3-и сутки жизни. Антенатальный перинатальный артериальный ишемический инсульт

А, Б - коронарное и парасагиттальное сечение; в проекции базальных ганглиев слева (головка хвостатого ялра, бледный шар) очаг повышенной эхогенности; В - ишемический очаг в проекции головки хвостатого ялра на магнитно-резонансной томограмме.

возраст $\geq 37$ нед) очаги ишемии локализуются в корковоподкорковой области в бассейне поверхностных ветвей СМА, чаще всего в левом полушарии (68,75\%) [1-7, $18,20]$. Размеры и локализация ишемических очагов очень вариабельны, зависят от уровня артериальной окклюзии и состояния коллатерального кровотока. Зона ишемии может распространяться на несколько долей полушария или занимать небольшой участок в пределах одной доли.

При УЗИ неонатальный ишемический инсульт выглядит как неоднородная зона умеренно повышенной эхогенности [4-7]. Контуры ишемических очагов очень нечеткие, поэтому точно измерить их размеры и оценить в динамике при узи очень сложно (рис. 3).

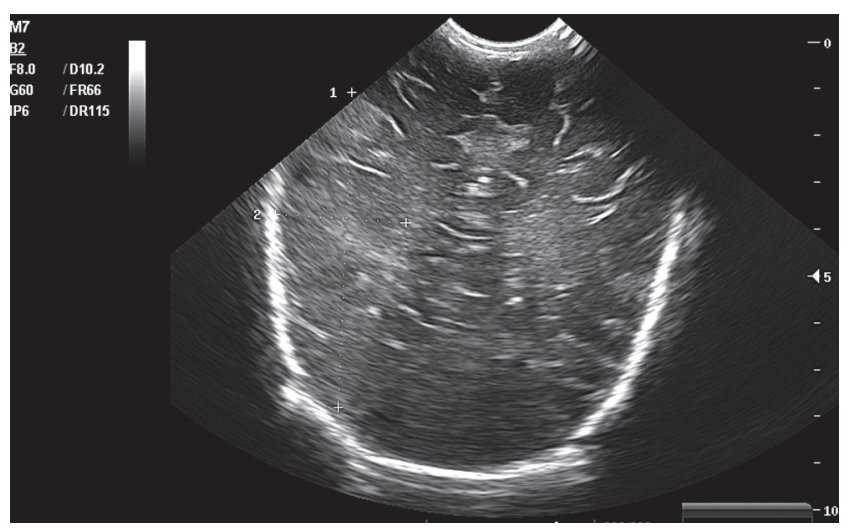

A
Неонатальные артериальные ишемические инсульты как правило, развиваются на 2-3-и сутки жизни [7]. Начинается ПАИИ остро и тяжело (судороги, апноэ, угнетение ЦНС, двигательные нарушения), что, естественно, является показанием для срочного проведения УЗИ мозга $[1-8,11,12$, 14, 20-22]. Однако в течение 1-2-го дня от манифестации заболевания ишемический очаг при УЗИ не виден [1, 4-7]. При тщательном и прицельном УзИ детей с характерной очаговой симптоматикой лишь иногда можно заметить небольшое снижение дифференцировки структур в одном из полушарий. Но, как правило, эти изменения недостоверные и очень спорные. И только к концу 2-го - началу 3-го дня заболевания при УзИ начинает проявляться зона ишемии [7].

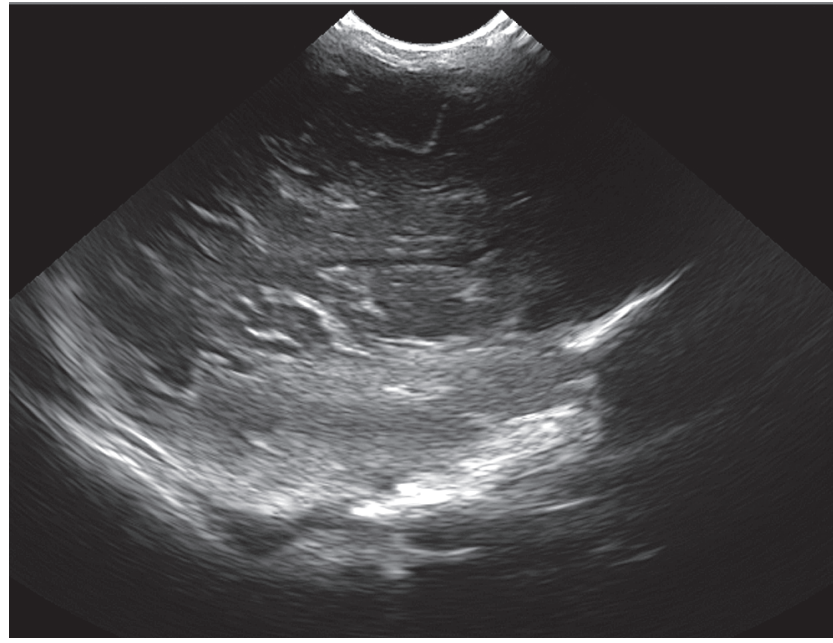

b

Рис. 3. Постнатальный артериальный ишемический инсульт. Ишемические очаги разной мокализации и разных размеров A - зона ишемии захватывает теменно-затылочную область слева; Б - зона ишемии в височной области. 


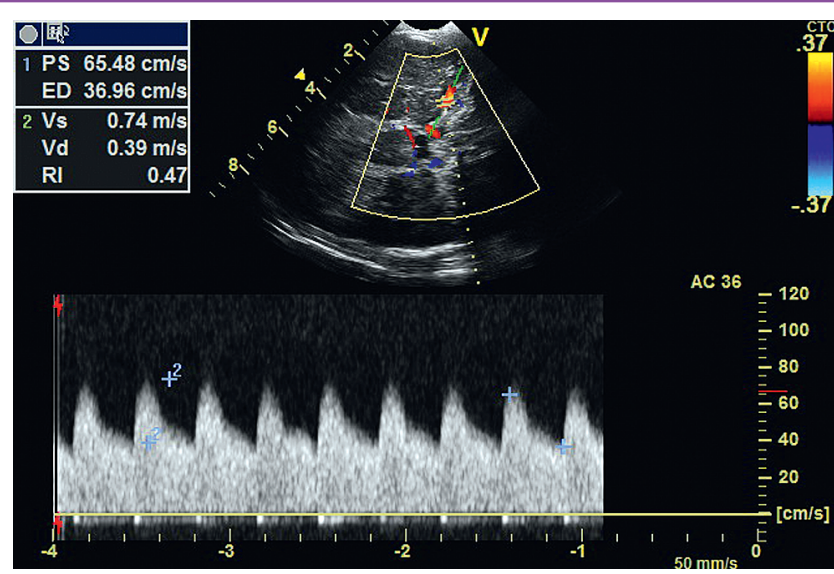

A

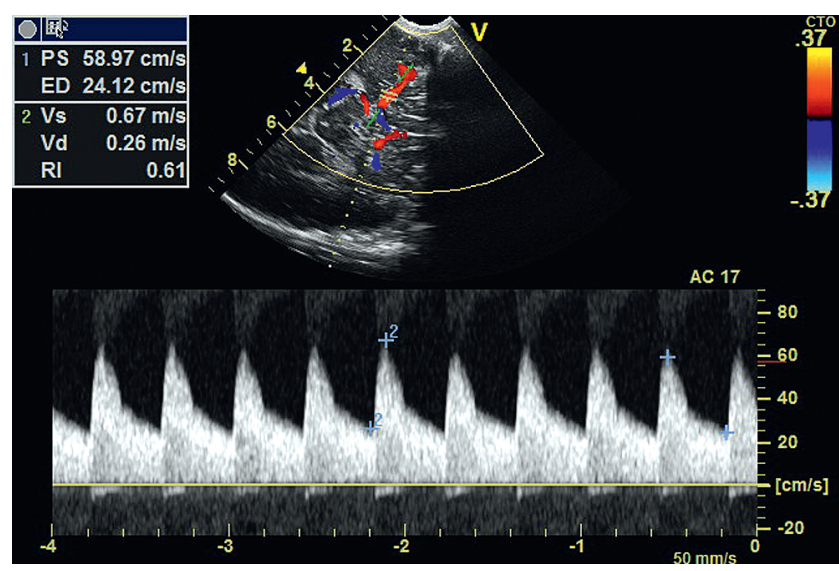

6

Рис. 4. Ребенок П., 39 нед гестации, оценка по шкале Апгар 8/8 балмов, 2-е сутки жизни. Аебют перинатального артериального ишемического инсульта. Очаговые изменения головного мозга не выявлены. Выраженная асимметрия кровотока по средней мозговой артерии (СМА)

A - Аопплерограмма кровотока по CMA слева: IR=0,47, Vs=74 cм/c; Б - Аопплерограмма кровотока по CMA справа: IR=0,61, $\mathrm{Vs}=0,67 \mathrm{~cm} / \mathrm{c}$.

В отличие от В-режима, дуплексное сканирование сосудов головного мозга уже с 1-го дня заболевания выявляет локальные изменения кровотока в пораженном полушарии $[4,6,7]$. При ИД на стороне инсульта отмечается увеличение скорости кровотока (Vs и Vd), а также снижение периферического сопротивления (IR) в CMA, нередко и в задней мозговой артерии. Эти изменения кровотока указывают на вазодилатацию и гиперперфузию в пораженном сосудистом бассейне, что характерно для реперфузии во вторую стадию инсульта $[4,6]$.

В непострадавшем полушарии показатели гемодинамики по СМА остаются в пределах нормы, т.е. скорости кровотока (Vs и Vd) ниже, а периферическое сопротивление (IR) выше, чем на стороне инсульта (рис. 4). Таким образом, при дуплексном сканировании сосудов головного мозга отмеча-

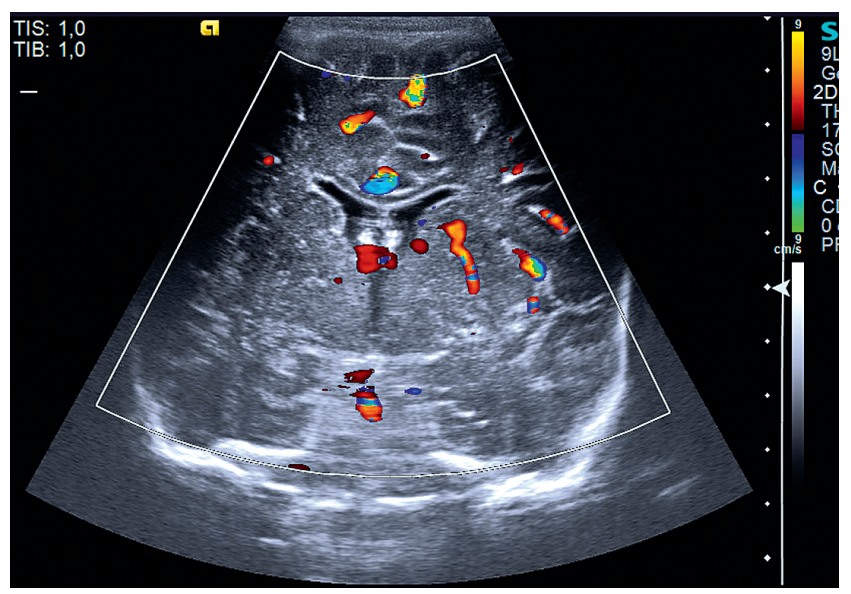

Рис. 5. Ребенок Р., 38 неА гестации, оценка по шкале Апгар 7/8 баммов, 2-е сутки жизни. Аебют перинатального артериального ишемического инсульта. В паренхиме левого полушария определяются множественные расширенные сосуды (поверхностные ветви среАней мозговой артерии) ется сторонняя асимметрия кровотока по СМА за счет усиления кровотока в пострадавшем сосудистом бассейне [7].

Кроме признаков вазодилатации основного ствола СМА при ИД, в режиме ЦДК в зоне ишемии у большинства детей $(n=10,71,4 \%)$ отмечалась усиленная васкуляризация, обусловленная расширением мелких ветвей СМА в результате вазопареза и гиперперфузии. При ИД в этих мелких сосудах также выявляется низкое периферическое сопротивление (рис. 5) [7].

Таким образом, выявление асимметрии кровотока по СМА говорит в пользу предполагаемого диагноза ПАИИ, является дополнительным показанием для проведения МРТ по расширенному протоколу с использованием МР-ангиографии (см. схему) [7].

С практической точки зрения необходимо отметить, что при назначении детям, находящимся в реанимации в тяжелом состоянии, нейросонографии с допплерографией врачи ультразвуковой диагностики не всегда исследуют кровоток по СМА с двух сторон, так как для этого требуется поворачивать голову ребенка в обе стороны, что бывает сложно выполнимо, требует помощи со стороны среднего медперсонала и дополнительного времени. Поэтому клинические врачи должны информировать специалиста ультразвуковой диагностики о подозрении на ПАИИ (появление очаговой неврологической симптоматики в сочетании с судорожным синдромом на 2-3-и сутки жизни) и отдельно указывать, что необходима оценка кровотока по СМА с двух сторон.

Состояние гемодинамики в пораженном сосудистом бассейне меняется во времени. На 3-5-й день от начала заболевания вазодилатация СМА сменяется вазоспазмом [7]. Периферическое сопротивление (IR) в стволе СMA на стороне инсульта повышается, становится выше, чем в здоровом полушарии, скорость кровотока снижается, особенно в Vd. Расширение мелких ветвей СМА в зоне инсульта может сохраняться еще в течение нескольких дней [7].

Вазоспазм СМА на стороне инсульта сохраняется длительно, нередко до 3-4 мес [7]. 


\section{КАинический случай}

Ребенок Ж., роды в срок. Оценка по шкале Апгар 8/9 баллов. В конце 1-х суток появились фокальные судороги справа. Из-за тяжести состояния переведен в отделение реанимации.

При УзИ на 2-е сутки жизни при прицельном осмотре достоверных изменений эхоструктуры мозга не выявлено. Отмечалось только легкое снижение дифференцировки структур в левом полушарии. Дуплексное сканирование выявило выраженную асимметрию кровотока по СМА (рис. 6). Периферическое сопротивление левой СМА было резко снижено, IR=0,51. Скорость кровотока (Vs и Vd) была повышена, превышала на $30 \%$ скорость кровотока в правой СМА. В паренхиме левого полушария определялись расширенные сосуды с низким периферическим сопротивлением. Гиперперфузия и вазопарез СМА слева косвенно указывали на ишемическое поражение левого полушария.

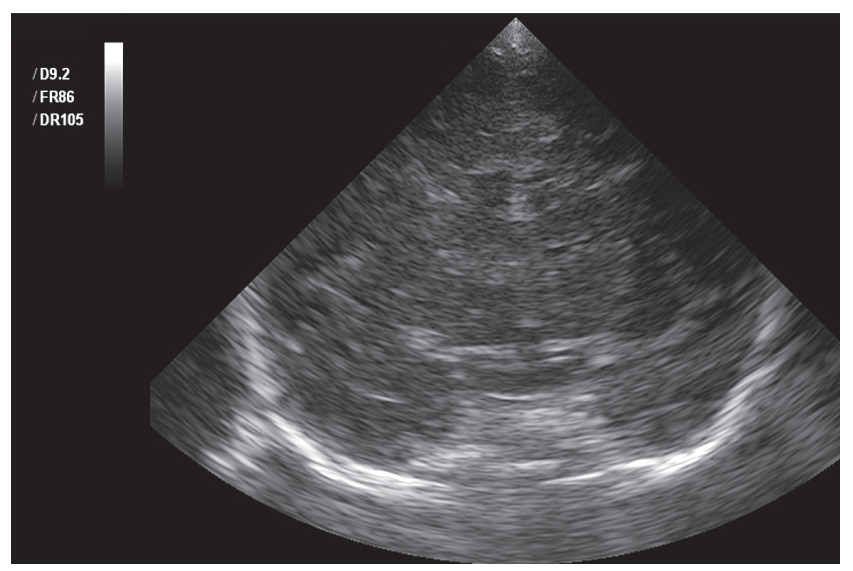

A

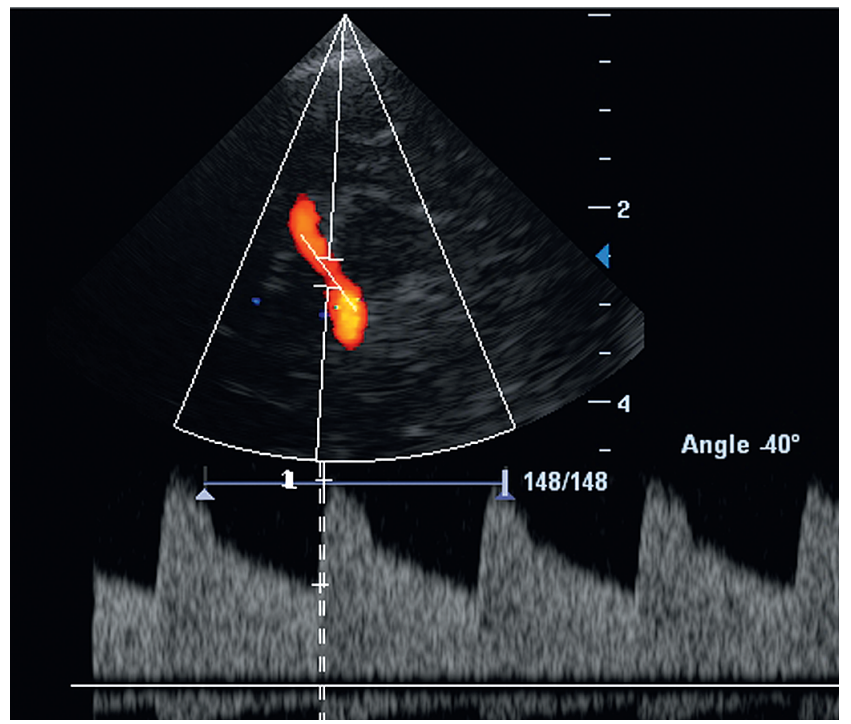

B
При повторном УзИ на 4-й день заболевания в лобнотеменных отделах левого полушария определялась зона повышенной эхогенности с нечеткими контурами (рис. 7). При дуплексном сканировании артерий основания мозга слева признаки вазодилатации сменились вазоспазмом (см. рис. 7В). Периферическое сопротивление СМА повысилось, причем слева (на стороне ишемии) оно было больше, чем справа. Скорость кровотока (Vs и Vd) по левой СМА стала ниже, чем справа, на 20\%. В паренхиме мозга слева сохранялись единичные расширенные ветви СМА с низким периферическим сопротивлением $(\mathrm{IR}=0,56)$.

При контрольном обследовании этого ребенка в 2 мес в СМА на стороне перенесенного инсульта сохранялись признаки вазоспазма в виде повышения периферического сопротивления и снижения скорости кровотока (Vs и Vd) (рис. 8). Стоит отметить, что очаговых изменений паренхимы при этом исследовании не выявлено. Отмечали только небольшое расширение и деформированность («подтя-

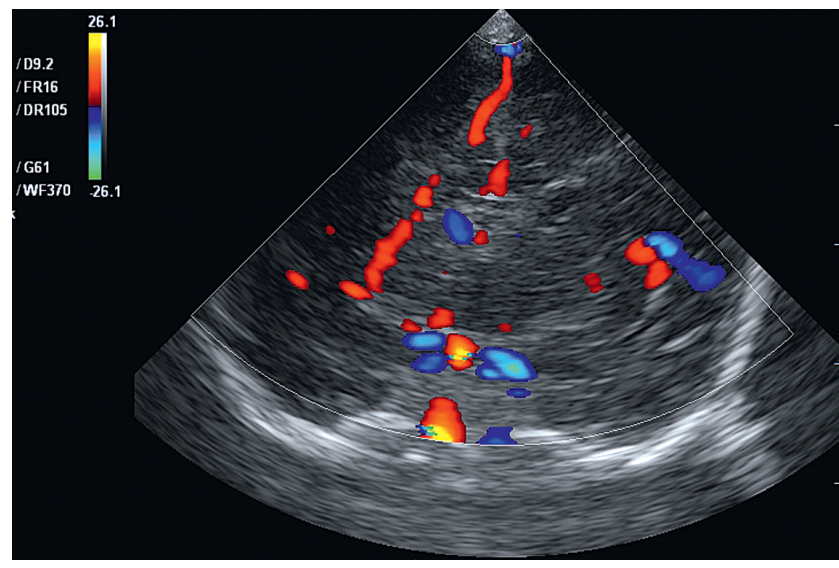

b

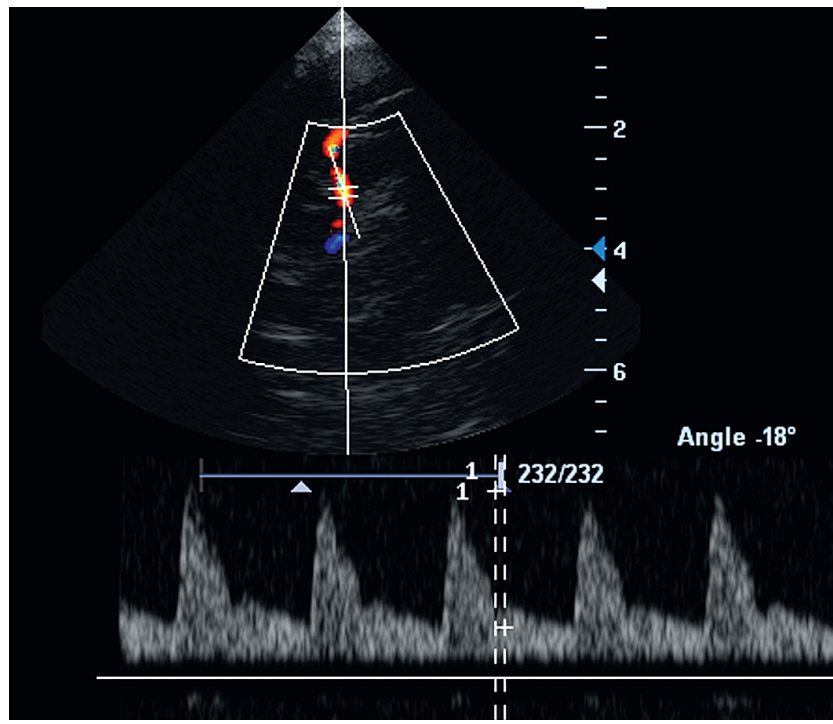

$\Gamma$

Рис. 6. Ребенок Ж., 2-е сутки жизни. Выраженная асимметрия кровотока по средней мозговой артерии (CMA)

A - эхограмма головного мозга: очаговых изменений нет, небольшое снижение дифференцировки структур левого полушария; Б - режим цветного Аопплеровского сканирования: в паренхиме левого полушария картируются расширенные сосуды; $B$ - Аопплерограмма кровотока по CMA слева - IR=0,51 - снижен, Vs=77 cM/c и Vd=38 cM/c - повышены; Г- Аопплерограмма кровотока по СMA справа - IR=0,73, Vs=51 cM/c, Vd=14 cM/c - норма. 
нутость») бокового желудочка на стороне перенесенного инсульта.

Не только в данном клиническом случае, но и в подавляющем большинстве наших наблюдений (14 детей) в отдаленном периоде ишемического инсульта УзИ не выявляло очаговых изменений. Отсутствие значимых изменений эхоструктуры мозга в отдаленном периоде, безусловно, не является признаком восстановления паренхимы. При МРТ в области перенесенного инсульта выявлялись очаги глиоза, которые при УзИ невозможно отличить от здоровых тканей мозга [17-19, 21, 22] (рис. 9).

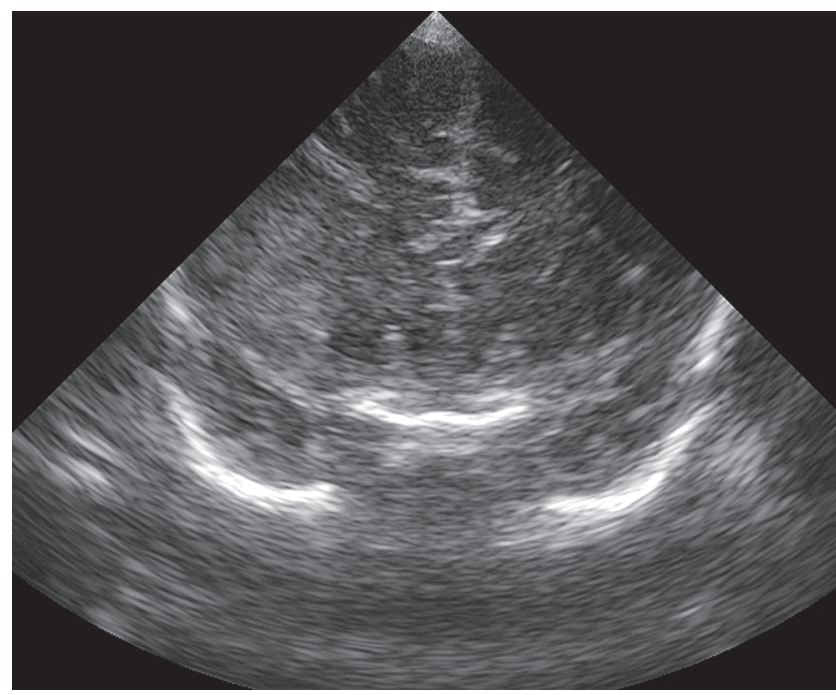

A

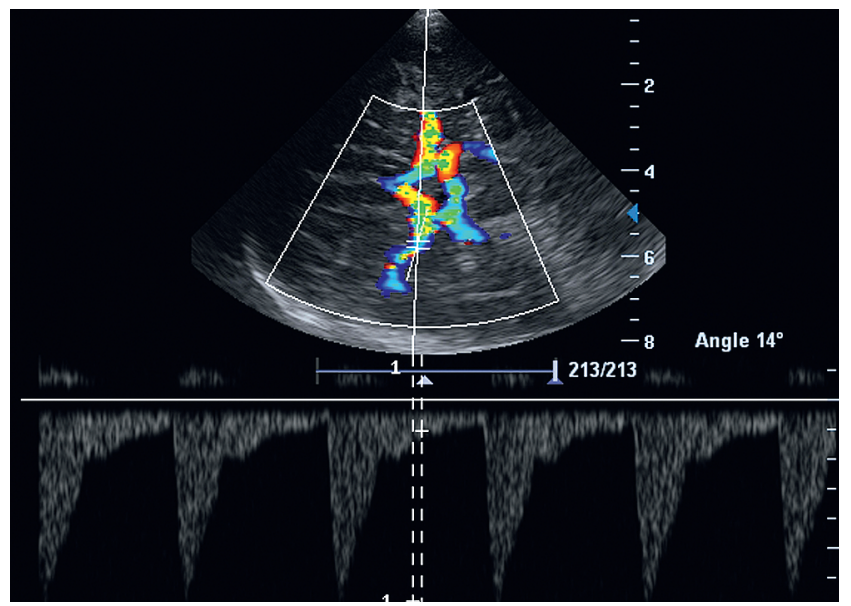

B

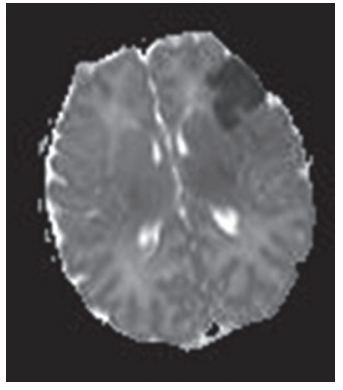

Д
Однако у части детей с ПАИИ (4 ребенка) на месте ишемического очага к концу 1-го месяца сформировались кистозные полости (рис. 10).

Основываясь на данных литературы и на наших собственных наблюдениях, можно выделить следующие характерные ультразвуковые особенности неонатального ишемического инсульта.

1. Ишемический очаг при УзИ определяется не ранее конца 2-го дня заболевания. Наиболее часто ишемические очаги располагаются в корково-подкорковой области в бассейне СМА, преимущественно в левом полушарии $[4,6,7]$.

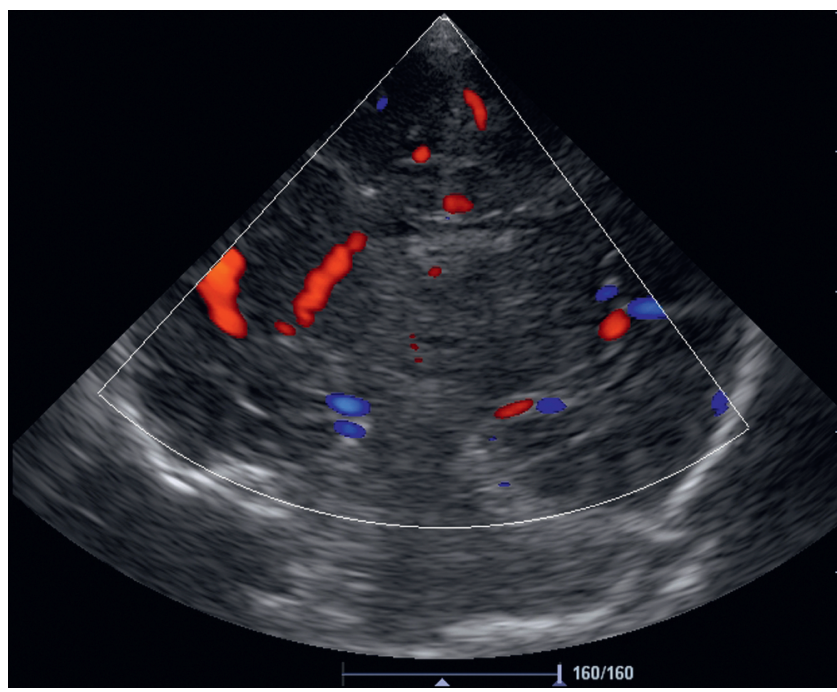

Б

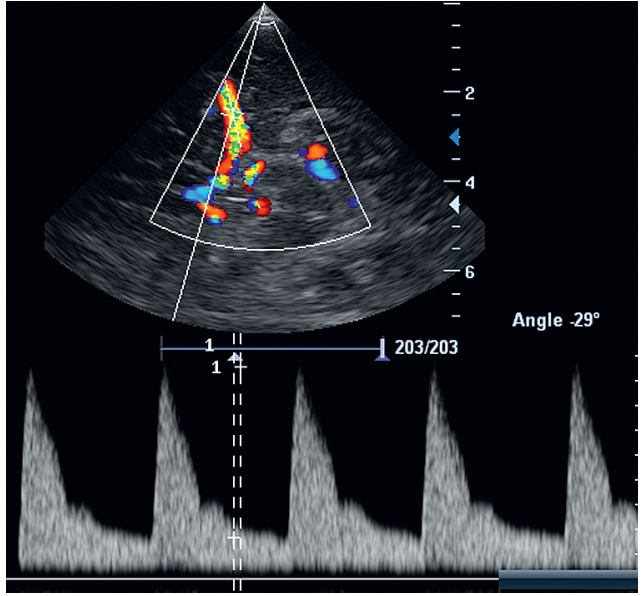

Рис. 7. Ребенок Ж., 4-е сутки жизни

А - эхограмма головного мозга: неоднородный очаг умеренно повышенной эхогенности в лобной Аоле левого полушария; 5 - режим центрального Аопплеровского картирования: в паренхиме левого полушария сохраняются расширенные сосуды; $B$ - Аопплерограмма кровотока по средней мозговой артерии слева - IR=0,85 - повышен, Vs=68 cм/с и Vd=10 cM/c - снижены; $\Gamma$ - Аопплерограмма кровотока по СМА справа - IR=0,8 повышен в меньшей степени, $V \mathrm{~s}=86 \mathrm{~cm} / \mathrm{c}-$ норма, $V d=17 \mathrm{~cm} / \mathrm{c}$; A - магнитно-резонансная томограмма на 3-и сутки жизни - очаг острого нарушения мозгового кровообращения в ^обной Аоле слева. 


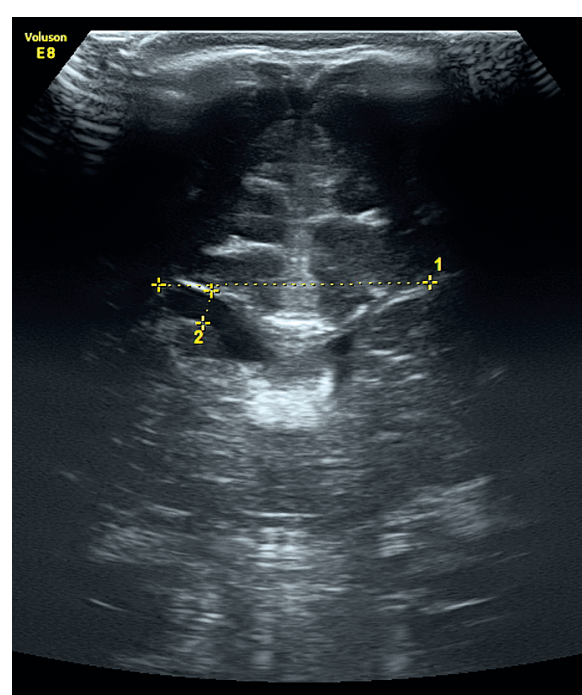

A

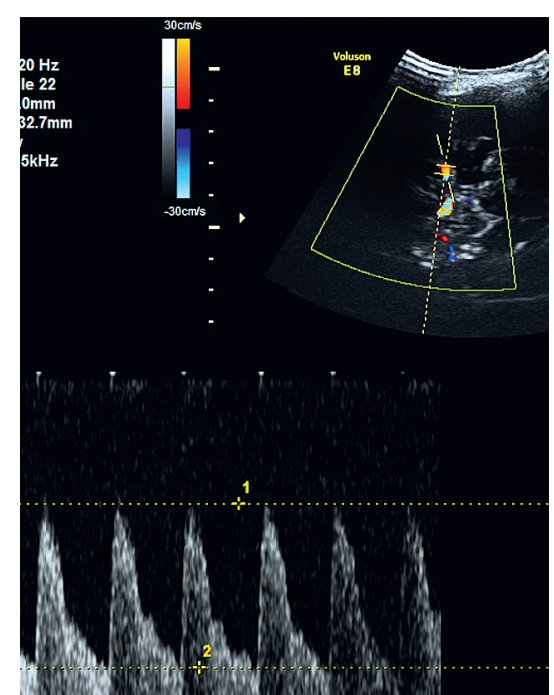

Б

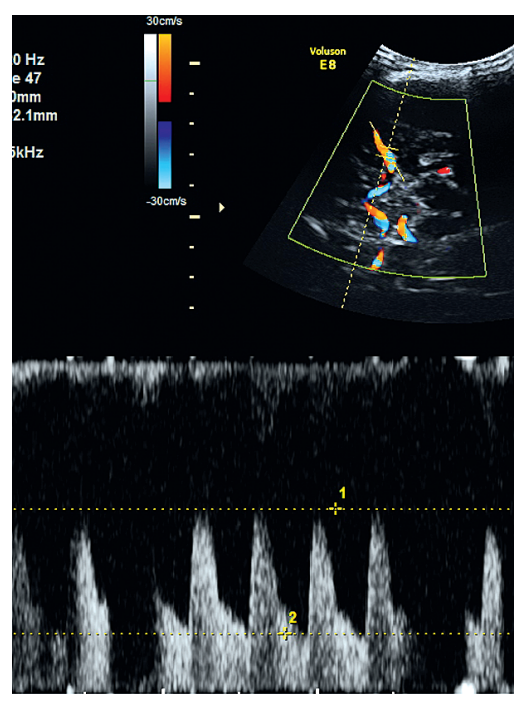

B

Рис. 8. Ребенок Ж., 2 мес

A - эхограмма головного мозга - очаговых изменений не выявлено, незначительное расширение бокового желудочка слева; Б - Аопплерограмма кровотока по средней мозговой артерии (CMA) слева - IR=0,75 - повышен, Vs=94см/с и Vd=23 см/с; B - Aопплерограмма кровотока по СMA справа: IR=0,67 - норма, Vs=113 cm/c- норма, Vd=37 cm/c.

2. В 1-2-е сутки заболевания, еще до визуализации зоны ишемии при УЗИ, в СМА и ее ветвях определяются допплерографические признаки вазодилатации и гиперперфузии в виде увеличения скорости кровотока (Vs и Vd) и снижения индекса периферического сопротивления $[4,6,7]$.

3. На 3-5-й день от начала заболевания вазодилатация основного ствола СМА сменяется вазоспазмом, резко увеличивается индекс периферического сопротивления. В мелких ветвях СМА вазодилатация сохраняется дольше, до 5-6-го дня заболевания [7].

4. Вазоспазм СМА на стороне пострадавшего сосудистого бассейна сохраняется длительно, до 3-4 мес [7].

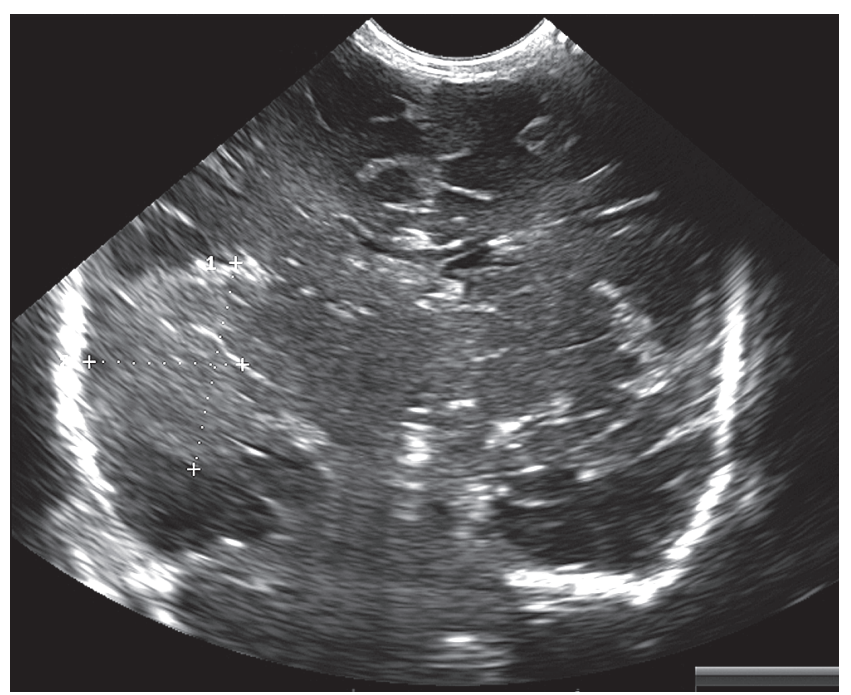

A
5. В отдаленном периоде на месте инсульта формируются кистозные полости [6], но при хорошем развитии глиоза структурные изменения паренхимы на УЗИ могут быть не видны (см. рис. 9Б).

Из вышесказанного очевидно, что клинические и ультразвуковые проявления неонатального и фетального ишемического инсульта у доношенных новорожденных имеют характерные существенные различия, обусловленные временем развития ишемии (см. таблицу).

Жизнеспособные недоношенные дети любого гестационного возраста тоже могут страдать от инсульта $[5,6]$. Однако данные о распространенности ПАИИ у недоношен-

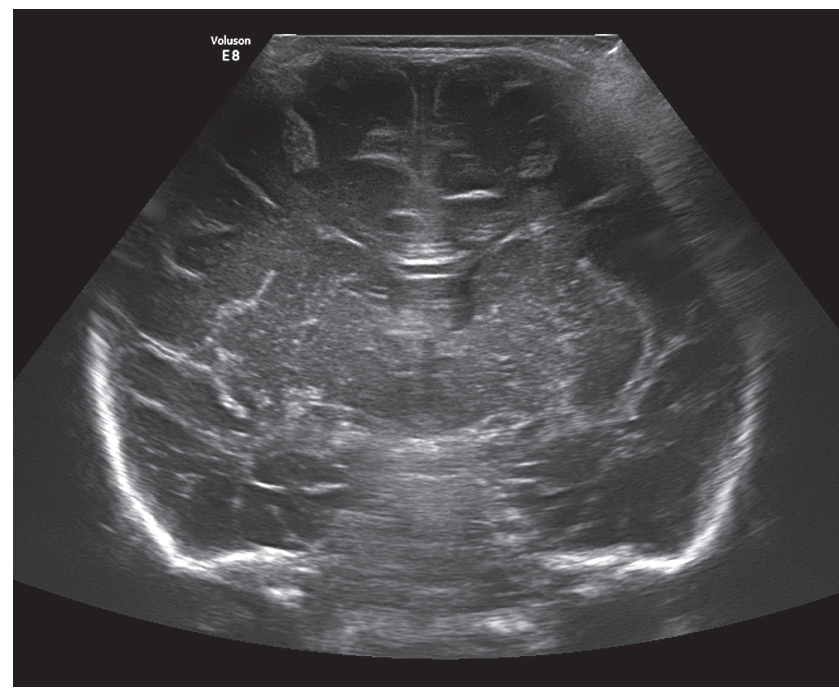

Б

Рис. 9. Ребенок У., 39 нед гестации, оценка по шкале Апгар 8/9 баммов

A - эхограмма мозга на 5-е сутки жизни: в височно-затылочной области слева обширная зона повышенной эхогенности; 5 - эхограмма мозга в 2 мес - очаговых изменений в паренхиме не выявлено, ликворная система не расширена. 


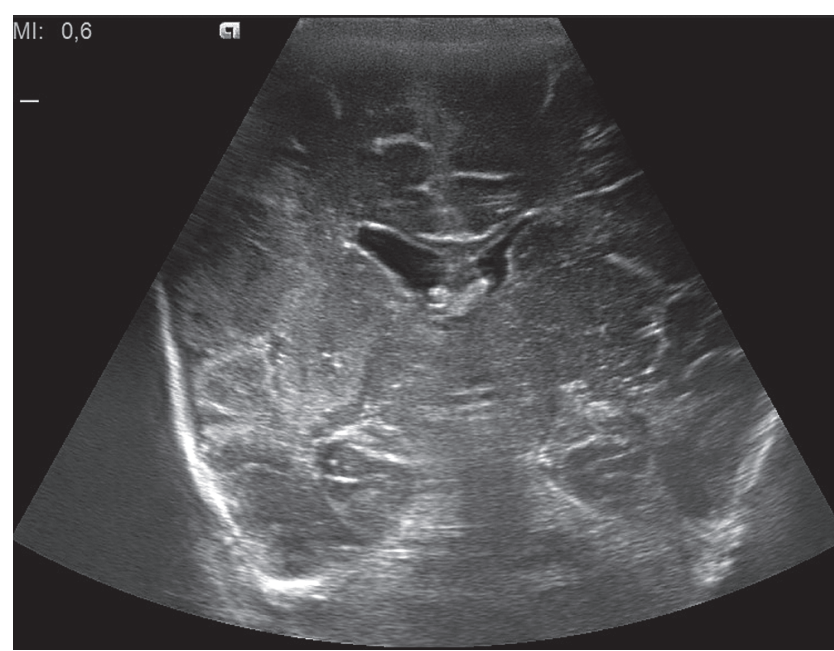

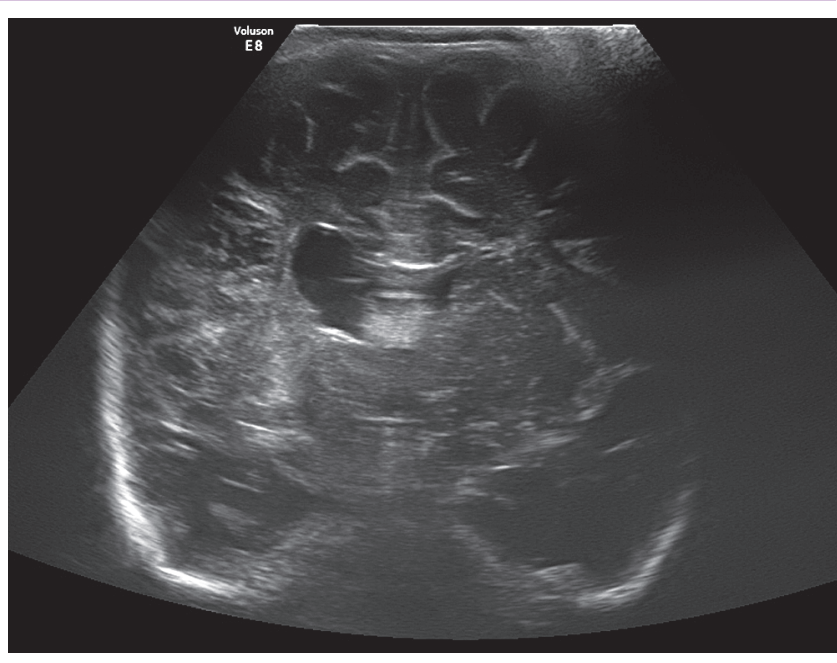

Б

Рис. 10. Ребенок, 38 нед гестации, оценка по шкале Апгар 7/8 бамлов, гастрошизис

A - эхограмма мозга на 11-е сутки жизни (4-й день после манифестации инсульта): обширная зона повышенной эхогенности, отечность тканей в ^обно-теменно-затылочной области слева; Б - эхограмма мозга в 1,5 мес: Аеструкция и кистозная дегенерация в лобно-теменно-затылочной области слева, расширение левого бокового желудочка.

ных детей скудны. Считается, что ПАИИ у недоношенных детей не сопровождаются неврологической симптоматикой, чаще всего локализуются в бассейне лентикулостриарных артерий $[5,6]$. Окклюзия крупных артерий у недоношенных детей встречается редко [6].

В ходе практической работы мы наблюдали несколько случаев развития ПАИИ у недоношенных детей $(n=3)$ со сроком гестации $>30$ нед. По нашим наблюдениям, ишемические инсульты у них развивались на 2-3-и сутки жизни. При Узи В В-режиме очаги повышенной эхогенности определялись у 2 детей в зрительном бугре (рис. 11), у 1 ребенка в проекции базальных ганглиев. При ИД у всех детей периферическое сопротивление СМА было повышено с двух сторон, асимметрии кровотока по СМА не выявлено. В режиме цДК и в энергетическом допплеровском режиме отмечалась гиперваскуляризация в очаге ишемии, которая указывала на локальный вазопарез лентикулостриарных артерий.

\section{Зак^ючение}

Безусловно, «золотым стандартом» нейровизуализации перинатальных инсультов является МРТ. Однако данный метод доступен не в каждом лечебном учреждении и не всегда дети могут быть доставлены к томографу в ранние сроки заболевания из-за тяжести состояния. В связи С этим возрастает роль УЗИ, которое можно использовать «у постели больного». В самые ранние сроки заболевания УзИ позволяет исключить другие виды структурной патологии головного мозга (объемные кровоизлияния и др.). Позже, при визуализации ишемического очага на УзИ, можно

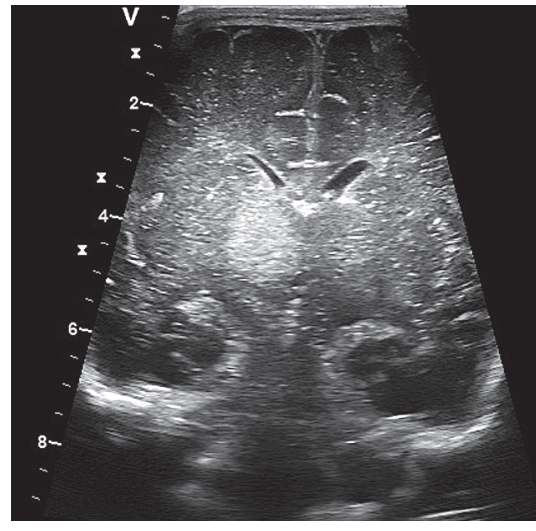

A

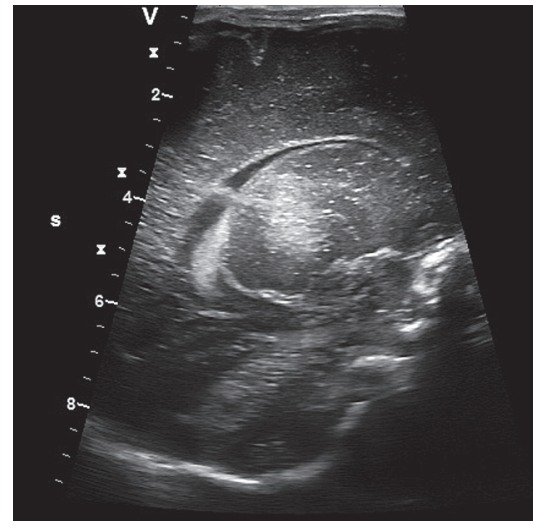

Б

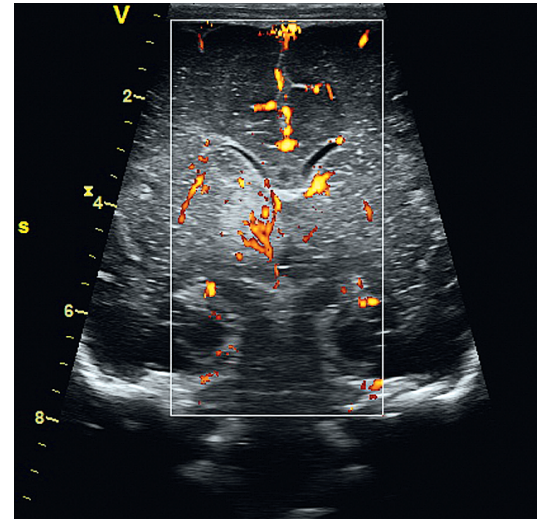

B

Рис. 11. Ребенок М., 35 неА гестации, 2-й из Авойни, оценка по шкале Апгар 7/8 баммов. При первичном ультразвуковом исследовании головной мозг без очаговой патологии

A, Б - очаг повышенной эхогенности в проекции зрительного бугра слева в коронарном и парасагиттальном сечении; В - режим энергетического допплера: усиление кровотока, расширение мелких сосудов (лентикулостриарных артерий) в очаге ишемии. 
Сравнительная характеристика разных типов перинатальных артериальных ишемических инсультов

\begin{tabular}{|c|c|c|c|}
\hline Показатель & $\begin{array}{c}\text { Антенатальный инсульт } \\
\text { у доношенных }\end{array}$ & $\begin{array}{c}\text { Постнатальный инсульт } \\
\text { у Аоношенных }\end{array}$ & $\begin{array}{c}\text { Постнатальный инсульт } \\
\text { у недоношенных }\end{array}$ \\
\hline $\begin{array}{l}\text { Кминические } \\
\text { проявления }\end{array}$ & Мышечная Аистония & $\begin{array}{l}\text { Судороги, апноэ, угнетение ЦНС, } \\
\text { Авигательные нарушения }\end{array}$ & $\begin{array}{l}\text { Апноэ, кратковременные } \\
\text { судороги }\end{array}$ \\
\hline ^окализация очага & $\begin{array}{l}\text { Базальные ганглии, } \\
\text { зрительные бугры }\end{array}$ & Корково-поАкорковые отАелы & $\begin{array}{l}\text { Базальные ганглии, зрительные } \\
\text { бугры }\end{array}$ \\
\hline $\begin{array}{l}\text { Кровоток по среАней } \\
\text { мозговой артерии }\end{array}$ & $\begin{array}{l}\text { Кровоток симметричный } \\
\text { или вазоспазм на стороне } \\
\text { ишемии }\end{array}$ & $\begin{array}{l}\text { Асимметрия кровотока, вазопарез } \\
\text { в острый период, вазоспазм после } \\
\text { 3-5-го Аня заболевания }\end{array}$ & Кровоток симметричный \\
\hline $\begin{array}{l}\text { Гиперваскуляризация } \\
\text { в очаге ишемии }\end{array}$ & Нет & Определяется в течение 5-6 Аней & Определяется в течение 5-6 Аней \\
\hline
\end{tabular}

оценить его локализацию и приблизительные размеры. Ультразвуковая допплерография повышает диагностическую ценность метода, помогает определить пострадавший сосудистый регион и давность его поражения. Выявление асимметрии кровотока по одноименным артериям является дополнительным показанием к проведению МРТ даже при отсутствии клинической симптоматики и достоверных очаговых изменений на УзИ. Ультразвуковой метод информативен и удобен для динамической оценки состояния паренхимы мозга и мозгового кровотока, которую мы рекомендуем проводить ежедневно в первые 5-7 дней заболевания и далее каждые 5-7 дней [7].

\section{CBEАЕНИЯ ОБ АВТОРАХ}

Быкова Юлия Константиновна (Yuliya K. Bykova) - кандидат медицинских наук, врач и научный сотрудник отдела ультразвуковой диагностики в неонатологии и педиатрии ФГБУ «НМИЦ АГП им. В.И. Кулакова» Минздрава России, доцент кафедры лучевой диагностики детского возраста ФГБОУ ДПО РМАНПО Минздрава России, Москва, Российская Федерация

E-mail:yulia.bykova@mail.ru

https://orcid.org/0000-0003-2423-9123

Ушакова Любовь Витальевна (Lyubov' v. Ushakova) - кандидат медицинских наук, невролог Научно-консультативного педиатрического отделения, научный сотрудник отделения хирургии, реанимации и интенсивной терапии новорожденных ФГБУ «НМИЦ АГП им. В.И. Кулакова» Минздрава России, Москва, Российская Федерация

E-mail:u1v@bk.ru

https://orcid.org/0000-0002-9409-5404

Филиппова Елена Александровна (Elena A. Filippova) - кандидат медицинских наук, руководитель отдела ультразвуковой диагностики в неонатологии и педиатрии ФГБУ «НМИЦ АГП им. В.И. Кулакова» Минздрава России, ассистент кафедры лучевой диагностики детского возраста ФГБОУ ДПО РМАНПО Минздрава России, Москва, Российская Федерация

E-mail: fla77@mail.ru

http://orcid.org/0000-0002-4964-1736

Ватолин Константин Владимирович (Konstantin V. Vatolin) - доктор медицинских наук, профессор кафедры лучевой диагностики детского возраста ФГБОУ ДПО РМАНПО Минздрава России, Москва, Российская Федерация

E-mail:k.vatolin@yandex.ru

Сугак Анна Борисовна (Anna B. Sugak) - доктор медицинских наук, старший научный сотрудник отдела ультразвуковой диагностики в неонатологии и педиатрии ФГБУ «НМИЦ АГП им. В.И. Кулакова» Минздрава России, Москва, Российская Федерация E-mail:sugak08@mail.ru

http://orcid.org/0000-0003-4509-4154

Амирханова Джанетта Юнусовна (Dzhanetta Yu. Amirkhanova) - невролог Научно-консультативного педиатрического отделения ФГБУ «НМИЦ АГП им. В.И. Кулакова» Минздрава России, Москва, Российская Федерация

E-mail: djenn83@gmail.ru

https://orcid.org/0000-0002-5923-6646

Быченко Владимир Геннадьевич (Vladimir G. Bychenko) - кандидат медицинских наук, врач-рентгенолог, заведующий отделением лучевой диагностики ФГБУ «НМИЦ АГП им. В.И. Кулакова» Минздрава России, Москва, Российская Федерация E-mail: v_bychenko@oparina4.ru

https://orcid.org/0000-0002-1459-4124

Зубков Виктор Васильевич (Viktor V. Zubkov) - доктор медицинских наук, профессор, директор Института неонатологии и педиатрии ФГБУ «НМИЦ АГП им. В.И. Кулакова» Минздрава России, профессор кафедры неонатологии Института здоровья детей ФГАОУ ВО Первый МГМУ им. И.М. Сеченова Минздрава России (Сеченовский Университет), Москва, Российская Федерация E-mail: viktor.zubkov@mail.ru https://orcid.org/0000-0001-8366-5208 


\section{\ИТЕРАТУРА}

1. Olivé G., Agut T., Echeverría-Palacio C.M., Arca G., García-Alix A. Usefulness of cranial ultrasound for detecting neonatal middle cerebra artery stroke // Ultrasound Med. Biol. 2019. Vol. 45, N 3. P. 885-890. DOI: 10.1016/j.ultrasmedbio.2018.11.004

2. Saliba E., Debillon T., Auvin S., Baud O., Biran V., Chabernaud J.L. et al.; Recommandations accident vasculaire cérébral (AVC) néonatal. Neonatal arterial ischemic stroke: review of the current guidelines // Arch. Pe diatr. 2017. Vol. 24, N 2. P. 180-188. DOI: 10.1016/j.arcped.2016.11.005

3. Husson B., Durand C., Hertz-Pannier L. Recommendations for imaging neonatal ischemic stroke // Arch. Pediatr. 2017. Vol. 24, N $9 S$. P. 9S19-9S27. DOI: 10.1016/S0929-693X(17)30327-5.

4. Deeg K.H. Sonographic and Doppler sonographic diagnosis of neonatal ischemic stroke // Ultraschall. Med. 2017. Vol. 38, N 4. P. 360-376. DOI: $10.1055 / \mathrm{s}-0043-114409$.

5. Martinez-Biarge M., Ferriero D.M., Cowan F.M. Perinatal arterial ischemic stroke // Handbook of Clinical Neurology. 2019. Vol. 162. P. 239-266.

6. An Atlas of Neonatal Brain Sonography. $2^{\text {nd }}$ ed. / Govaert P. De Vries L.S. Mac Keith Press, 2010. 419 p.

7. Ушакова ^.В, Быкова Ю.К., Быченко В.Г., Филиппова Е.А., Струтынская А.А. Клинико-диагностические критерии перинатального арте риального ишемического инсульта у Аетей // Неонатология: новости, мнения, обучение. 2017. № 4. С. 104-112.

8. Нароган М.В., Быченко В.Г., Ушакова А.В., Амирханова А.Ю., Рюмина И.И., Артамкина Е.И. и Ар. Перинатальный артериальный ишеми ческий инсульт: частота, Аиагностика, варианты клинического течения, ранние исходы // Педиатрия. Журнал им. Г.Н. Сперанского. 2019. Т. 98 № 2. C. $35-42$.

9. Raju T.N., Nelson K.B., Ferriero D., Lynch J.K. Ischemic perinatal stroke: summary of a workshop sponsored by the National Institute of Child Health and Human Development and the National Institute of Neurological Disorders and Stroke // Pediatrics. 2007. Vol. 120. P. 609-616. DOI: 10.1542/peds.2007-0336.

10. Lynch J.K. Epidemiology and classification of perinatal stroke // Semin. Fetal Neonatal Med. 2009. Vol. 14. P. 245-249. DOI:_10.1016/ j.siny.2009.07.001.
11. Grunt S., Mazenauer L., Buerki S.E., Boltshauser E. et al. Incidence and outcomes of symptomatic neonatal arterial ischemic stroke // Pediatrics. 2015. Vol. 135. P. e1220-e1228. DOI: 10.1542/peds. 2014-1520.

12. Kirton A., Armstrong-Wells J., Chang T., Deveber G. et al.; Inter national Pediatric Stroke Study Investigators. Symptomatic neonatal arterial ischemic stroke: the international pediatric stroke study // Pediat rics. 2011. Vol. 128. P. e1402-e1410. DOI: 10.1542/peds.2011-1148.

13. Gunny R.S., Lin D. Imaging of perinatal stroke // Magn. Reson. Im aging Clin. N. Am. 2012. Vol. 20. P. 1-33. DOI: 10.1016/j.mric.2011.10.001.

14. Hamid I.S., Mueed Z.A. Perinatal arterial ischaemic stroke: an update with literature review // J. Pak. Med. Assoc. 2008. Vol. 58, N 7. P. 395-399.

15. Badve C.A., Khanna P.C., Ishak G.E. Neonatal ischemic brain injury: what every radiologist needs to know // Pediatr. Radiol. 2012. Vol. 42 P. 606-619. DOI: 10.1007/s00247-011-2332-8.

16. Kirton A., deVeber G. Advances in perinatal ischemic stroke // Pediatr. Neurol. 2009. Vol. 40. P. 205-214. DOI: 10.1016/j.pediatrneurol.2008.09.018.

17. Armstrong-Wells J., Ferriero D.M. Diagnosis and acute management of perinatal arterial ischemic stroke // Neurol. Clin. Pract. 2014 Vol. 4. P. 378-385. DOI: 10.1212/CPJ.0000000000000077.

18. Sehgal A. Perinatal stroke: a case-based review // Eur. J. Pediatr. 2012. Vol. 171. P. 225-234. DOI: 10.1007/s00431-011-1509-3.

19. Lee S., Mirsky D.M., Beslow L.A. Pathways for neuroimaging of neonatal stroke // Pediatr. Neurol. 2017. Vol. 69. P. 37-48. D0I: 10.1016/ j.pediatrneurol.2016.12.008.

20. Fernandez-Lopez D., Natarajan N, Ashwal S. Mechanisms of perinatal arterial ischemic stroke // J. Cereb. Blood Flow Metab. 2014. Vol. 34 P. 921-932. DOI: 10.1038/jcbfm.2014.41.

21. Ilves P., Laugesaar R., Loorits D., Kolk A. et al. Perinatal stroke: risk factors, clinical and radiological findings presumed // J. Child Neurol. 2016. Vol. 31, N 5. P. 621-629. DOI: 10.1177/ 0883073815609149.

22. Lehman L.L., Rivkin R.J. Perinatal arterial ischemic stroke: presentation, risk factors, evaluation, and outcome // Pediatr. Neurol. 2014 Vol. 51. P. 760-768. DOI: 10.1016/j.pediatrneurol. 2014.07.031.

\section{REFERENCES}

1. Olivé G., Agut T., Echeverría-Palacio C.M., Arca G., García-Alix A. Usefulness of cranial ultrasound for detecting neonatal middle cerebral artery stroke. Ultrasound Med Biol. 2019; 45 (3): 885-90. DOI: 10.1016/j.ultrasmedbio.2018.11.004.

2. Saliba E., Debillon T., Auvin S., Baud O., Biran V., Chabernaud J.L., et al.; Recommandations accident vasculaire cérébral (AVC) néonatal. Neonatal arterial ischemic stroke: review of the current guidelines. Arch Pediatr 2017; 24 (2): 180-8. DOI: 10.1016/j.arcped.2016.11.005.

3. Husson B., Durand C., Hertz-Pannier L. Recommendations for im aging neonatal ischemic stroke. Arch Pediatr. 2017; 24 (9S): 9S19-27. DOI: 10.1016/S0929-693X(17)30327-5.

4. Deeg K.H. Sonographic and Doppler sonographic diagnosis of neonatal ischemic stroke. Ultraschall Med. 2017; 38 (4): 360-76. DOI: $10.1055 / \mathrm{s}-0043-114409$.

5. Martinez-Biarge M., Ferriero D.M., Cowan F.M. Perinatal arterial ischemic stroke. In: Handbook of Clinical Neurology. 2019; 162: 239-66.

6. An Atlas of Neonatal Brain Sonography. 2nd ed. In: Govaert P., De Vries L.S. Mac Keith Press, 2010: 419 p.

7. Ushakova L.V., Bykova Yu.K., Bychenko V.G., Filippova E.A., Strutinskaya A.D. Clinical and diagnostic criteria for perinatal arterial ischemic stroke in children. Neonatologiya: novosti, mneniya, obuchenie [Neonatology: News, Opinions, Training]. 2017; (4): 104-12. (in Russian)

8. Narogan M.V., Bychenko V.G., Ushakova L.V., Amirkhanova D.Yu., Ryumina I.I., Artamkina E.I., et al. Perinatal arterial ischemic stroke: frequency, diagnosis, variants of clinical course, early outcomes. Pediatriya. Zhurnal im. G.N. Speranskogo [Pediatrics Journal named after G.N. Speranskiy]. 2019; 98 (2): 35-42. (in Russian)

9. Raju T.N., Nelson K.B., Ferriero D., Lynch J.K. Ischemic perinatal stroke: summary of a workshop sponsored by the National Institute of Child Health and Human Development and the National Institute of Neurological Disorders and Stroke. Pediatrics. 2007; 120: 609-16. DOI: 10.1542/peds.2007-0336.

10. Lynch J.K. Epidemiology and classification of perinatal stroke. Semin Fetal Neonatal Med. 2009; 14: 245-9. DOI: 10.1016/ j.siny.2009.07.001.
11. Grunt S., Mazenauer L., Buerki S.E., Boltshauser E., et al. Incidence and outcomes of symptomatic neonatal arterial ischemic stroke. Pediatrics. 2015; 135: e1220-8. DOI: 10.1542/peds.2014 1520.

12. Kirton A., Armstrong-Wells J., Chang T., Deveber G., et al.; International Pediatric Stroke Study Investigators. Symptomatic neonatal arteria ischemic stroke: the international pediatric stroke study. Pediatrics. 2011 128: e1402-10. DOI: 10.1542/peds.2011-1148.

13. Gunny R.S., Lin D. Imaging of perinatal stroke. Magn Reson Im aging Clin N Am. 2012; 20: 1-33. DOI: 10.1016/j.mric.2011.10.001.

14. Hamid I.S., Mueed Z.A. Perinatal arterial ischaemic stroke: an update with literature review. J Pak Med Assoc. 2008; 58 (7): 395-9.

15. Badve C.A., Khanna P.C., Ishak G.E. Neonatal ischemic brain in jury: what every radiologist needs to know. Pediatr Radiol. 2012; 42: 606 19. DOI: $10.1007 / \mathrm{s} 00247-011-2332-8$.

16. Kirton A., deVeber G. Advances in perinatal ischemic stroke. Pediat Neurol. 2009; 40: 205-14. DOI: 10.1016/j.pediatr-neurol.2008.09.018.

17. Armstrong-Wells J., Ferriero D.M. Diagnosis and acute management of perinatal arterial ischemic stroke. Neurol Clin Pract. 2014; 4: 37885. DOI: 10.1212/CPJ.0000000000000077.

18. Sehgal A. Perinatal stroke: a case-based review. Eur J Pediatr. 2012; 171: 225-34. DOI: 10.1007/s00431-011-1509-3.

19. Lee S., Mirsky D.M., Beslow L.A. Pathways for neuroimaging of neonatal stroke. Pediatr Neurol. 2017; 69: 37-48. DOI: 10.1016/ j.pediatrneurol.2016.12.008

20. Fernandez-Lopez D., Natarajan N, Ashwal S. Mechanisms of perinatal arterial ischemic stroke. J Cereb Blood Flow Metab. 2014; 34: 921 32. DOI: $10.1038 / \mathrm{jcbfm} .2014 .41$.

21. Ilves P., Laugesaar R., Loorits D., Kolk A., et al. Perinatal stroke: risk factors, clinical and radiological findings presumed. J Child Neurol. 2016; 31 (5): 621-9. DOI: 10.1177/ 0883073815609149.

22. Lehman L.L., Rivkin R.J. Perinatal arterial ischemic stroke: presentation, risk factors, evaluation, and outcome. Pediatr Neurol. 2014; 51 760-8. DOI: 10.1016/j.pediatrneurol. 2014.07.031. 